\title{
上咽頭癌の臨床的検討
}

$\begin{array}{lll}\text { 小林 } & \text { 吉史・林 } & \text { 達哉・今田 } \\ \text { 正信 } \\ \text { 野中 } \\ \text { 聡・原㴊 }\end{array}$

\section{A Clinical Study of Nasopharyngeal Cancer}

\author{
Yoshifumi Kobayashi, Tatsuya Hayashi, Masanobu Imada, \\ Satoshi Nonaka and Yasuaki Harabuchi \\ (Asahikawa Medical College)
}

\begin{abstract}
The outcomes of 40 cases of nasopharyngeal cancer (NPC), treated in our hospital between November 1976 and December 1998, were evaluated. Factors that appeared to influence prognosis were assessed by the Kaplan-Meier method. The ages of the patients ranged from 17 to 78 years. There were 28 males and 12 females.

The cumulative five-year survival rate for the whole study population was $45.1 \%$. The UICC classification (1997) was used for disease staging. The percentages of patients survival after fiveyears were: $100 \%$ for stage I ( 5 case), $71.4 \%$ for stage II B (9 cases), $11.4 \%$ for stage III ( 9 cases), $33.3 \%$ for stage $\mathrm{NA}$ ( 3 cases), $53.6 \%$ for stage $\mathrm{NB}$ ( 7 cases), and $0 \%$ for stage $\mathrm{NC}(3$ cases). The histological type with the highest survival rate was keratinizing type which had a $33.3 \%$ (10 cases) survival rate. The anatomical sites of primary tumors with the survival rate were $54 \%$ for the posterior wall ( 25 cases) and $36 \%$ for the lateral wall (10 cases). The survival rate according to classification based on initial therapy were as follows: radiotherapy alone group, $49.4 \%$ (20 cases) ; combined radiotherapy and chemotherapy group, 34.4\% (14 cases). Since the most frequent cases of death was distant metastasis $(67 \%)$, we suggest that the prevention of distant metastasis is important.
\end{abstract}

Key words : clinical study, nasopharyngeal cancer, NPC, survival rate

はじめに

当科で診断治療した上咽頭上皮性悪性腫瘍は44例存在 した. このらち扁平上皮癌は 40 例と最も多く, その他粘 表皮癌 2 例, 腺様囊胞癌 1 例, 多形腺腫内癌 1 例であっ た。

今回はこの扁平上皮癌 40 例の年齢, 性別, 原発部位, 組織型, 病期, 治療法などの背景と治療成績をまとめた ので報告する.

対象と方法 1976年11月の当科開設から1998年12月までの 22 年 1 カ
月間に旭川医科大学耳鼻咽喉科で䛦断治療した上咽頭扁 平上皮癌 40 例を対象とした. 生存例の観察期間は 5 244カ月, 中央值101カ月であった.

病期は局所所見のほか CT, MRI，ガリウムシンチ， 骨シンチなどを施行して決定し，旧分類と新分類で比較 した．病理組織は WHO 分類で再度検討した。

治療は原則として1986年までは放射線療法単独で行い, それ以降は放射線療法と化学療法を併用した。あた1995 年以降は放射線療法と化学療法を同時併用した。

放射線治療単独群では. ${ }^{60} \mathrm{Co}$ の $\gamma$ 線あるいはリニアッ ク $4 \mathrm{MVX}$ 線を用いて $50 \sim 80 \mathrm{~Gy}$ 照射した。照射方法は 
左右対向 2 門, 照射野は原則として原発巣とともに全頸 部を含んだ.

化学療法は原則として CDDP $\left(80 \mathrm{mg} / \mathrm{m}^{2}\right)$ を 1 日間と $5-\mathrm{FU}\left(500 \mathrm{mg} / \mathrm{m}^{2}\right)^{1)} 5$ 日間を 1 クールとして 2 あるい は 3 クール施行した.

疾患特異的生存率の算出にはカプラン・マイヤー法を, 有意差検出にはログランクテストを用い， $5 \%$ 未満の危 険率を有意とした。

\section{結 果}

1 . 性・年齢

男性28例, 女性12例, 男女比は 2.3 対 1 であった。 年 齡分布は17〜78歳におよび，40歳以上に多くみられた. 発症のピークは男性, 女性とも60歳代にあった. 年龄の 中央值は男性 63 歳, 女性51歳で全体は62歳であった(図 1 ).

2 . 原発部位・初発症状

原発部位は後上壁型が 27 例 (68\%), 側壁型が11例 $(28$ \%), 下壁型が 2 例 ( $5 \%$ )であった.

初発症状は頸部リンパ節腫脹が最も多く，21例(53\%) であった。このうち視診で上咽頭に病変が認められな かったが上咽頭の生検で診断されたものが 6 例(15\%) あった。次いで難聴, 耳閉感, 耳痛などの耳症状が 9 例 (23\%), 鼻出血が 5 例(13\%), 鼻閉 2 例 ( $5 \%$ )であった.

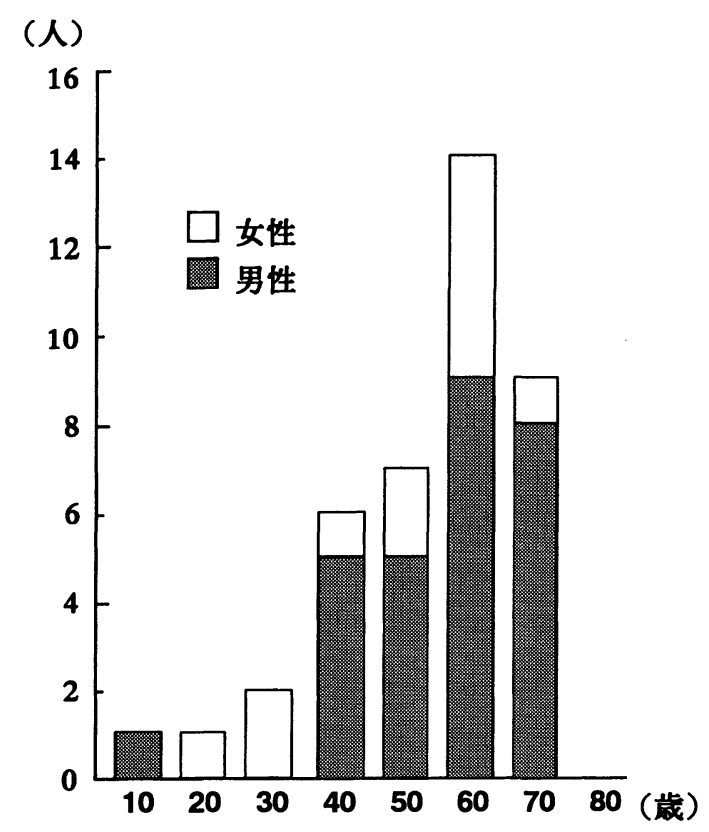

図 1 年齢・性別分布
また複視, 燕下時痛, 咽頭違和感が各 1 例ずつ存在した.

耳症状を呈した症例は側壁型に $55 \%$ と高率に認められ たのに対し, 鼻症状を呈した症例の $80 \%$ 以上が後上壁型 であった．視診で上咽頭に病変が認められず最終的に上 咽頭の生検で診断されたものが 6 例(15\%)存在した.

\section{3 . 病理組織像}

分類可能な37例をWHO 分類 (1991年)2) で再分類した. 角化型は 10 例 $(27 \%)$, 非角化・分化型は17例 (46\%), 未 分化型は10例(27\%)であった.

未分化型はすべて後上壁型であり，上咽頭に病変が認 められなかったが生検で診断された 6 例中 4 例 $(67 \%)$ が 末分化型であった。

\section{4. 病期}

TNM 分類叔よび病期分類は UICC で定めた旧分類 (1987年) ${ }^{3)}$ そ执いてT分類では T1：14例(35\%)，T2： 11例(28\%), T3 : 2 例 ( $5 \%$ ), T4:13例(32\%). N分 類では N0：11例(28\%), N1：6 例(15\%), N2：13例(33 $\%$ ，N3：10例(25\%)であった。病期は I 期が 2 例 ( 5 $\%)$ ，II期が 3 例 ( $8 \%)$ ，III期が 4 例(10\%)， N 期が31 例(78\%)であった.

これらを新分類(1997年)4) とよって再分類した結果, $\mathrm{T}$ 分類では $\mathrm{T} 1: 25$ 例 (63\%), T2b : 2 例 ( $5 \%), \mathrm{T} 3$ : 8 例 (20\%), T4 : 5 例 (13\%). N分類では N0 : 11例 $(28$ $\%), \mathrm{N} 1: 11$ 例(28\%), N2:8例(20\%), N3(a) : 10例(25 \%)であった．初診時すでに遠隔転移のあったものは 4 例(10\%)であった(表 1 ).

病期は I 期が 5 例 (13\%)，IIA期が 0 例 ( $0 \%)$, IIB

表 1 病期分類 (新分類)

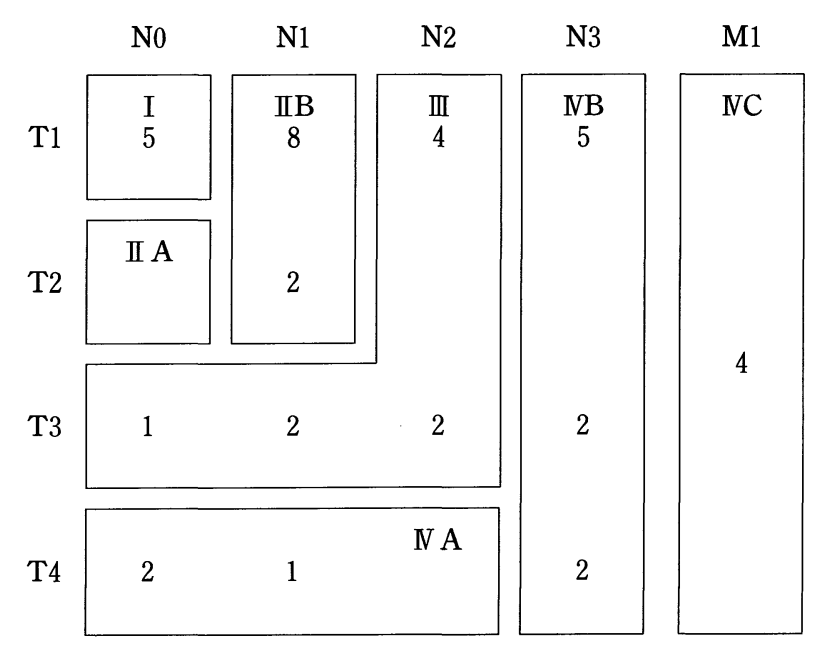




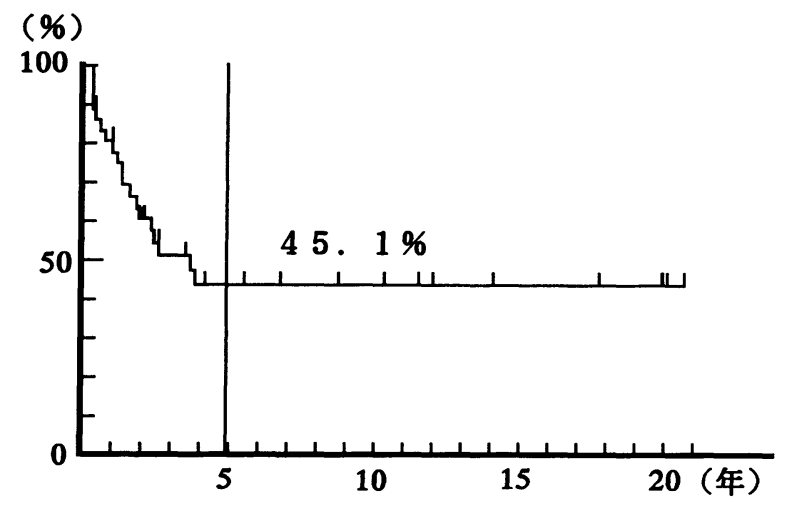

図 2 疾患特異的 5 年生存率

期が 10 例 (25\%)， III期が 9 例 (23\%)，NA期が 3 例 ( 8 $\%), \mathrm{NB}$ 期が 9 例 (23\%)， NC期が 4 例(10\%)であった.

5 . 治療成績

治療は40例中36例に施行可能であった．施行できな かった 4 例は全身状態が悪く，治療を中断したものが 2 例, 治療拒否が 2 例であった。

放射線療法単独は20例 ( I 期 4 例, IIB 期 8 例, III 期 4 例, NA期 2 例, NB期 1 例, NC期 1 例), 放射線化
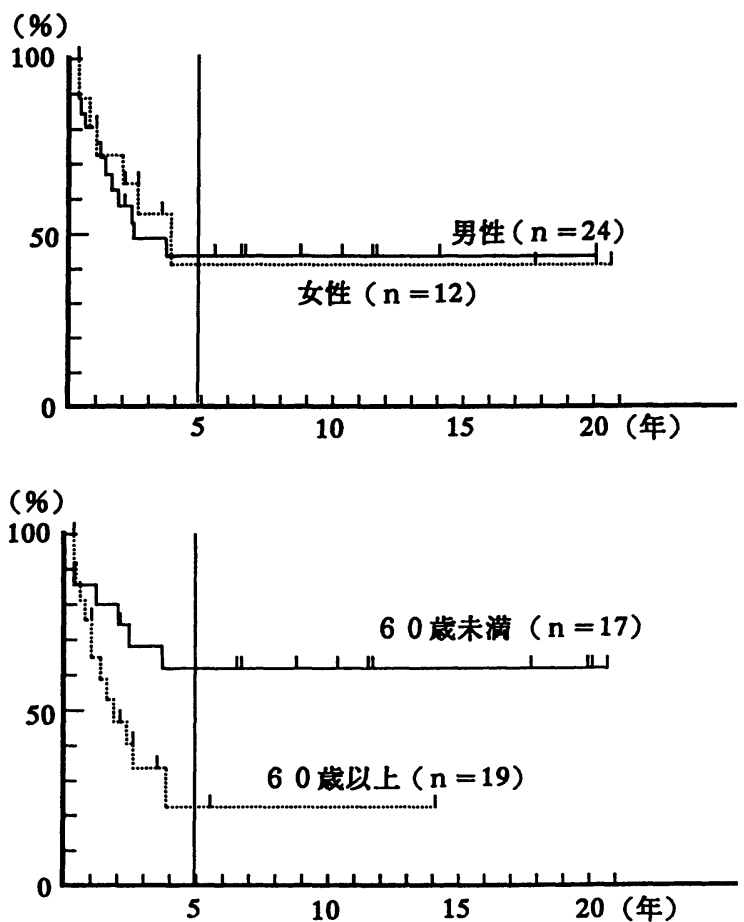

学療法併用は14例 ( I 期 1 例, IIB期 1 例, III期 4 例, NA期 1 例， NB期 5 例， NC期 2 例)であった.

放射線療法と頸部郭清術を併用した例が 2 例 (III期, NB期)存在した.

治療可能であった 36 例の疾患特異的 5 年生存率は 45.1 \%であった(図 2 ).

各予後因子について疾患特異的 5 年生存率を比較検討 した．性別では男性 $(n=24) 45.1 \%$ ，女性 $(n=12) 42.9$ \%であり有意差は認めなかった。年齢では 60 歳末満 $(\mathrm{n}=17)$ では64.2\%，60歳以上 $(\mathrm{n}=19)$ では23.2\%であ り，有意に高齢で 5 年生存率が低下していた $(\mathrm{p}<0.05)$. 原発部位別では後上壁型 $(\mathrm{n}=25)$ が $54 \%$, 側壁型 $(\mathrm{n}=10)$ が36\%，下壁型 $(n=1)$ が $0 \%$ であり後上壁型と側壁型 の間に有意差は認めなかった。組織型別では角化型 $(n=10)$ は33.3\%，非角化・分化型 $(n=17)$ は $22.9 \%$, 未分化型 $(n=9)$ は77.8\%であり各組織間で有意差は認 めなかった(図 3 ).

病期では旧分類では I 期 $(n=2)$ が $100 \%$, II 期 $(n=3)$

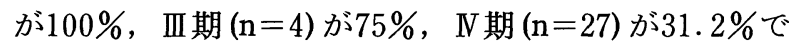
あった. 早期 ( I 期と III期) では進行期 (III期と IV 期) に比 較して有意に予後良好であった(図 4 ).
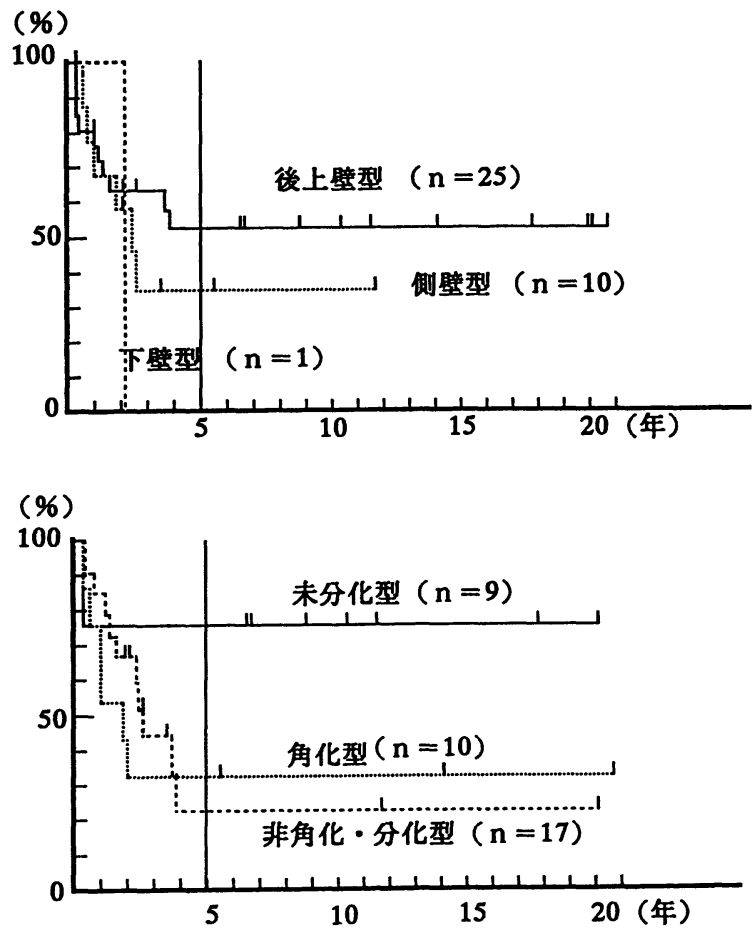

図 3 性別・年齢・原発部位・組織型別生存率 

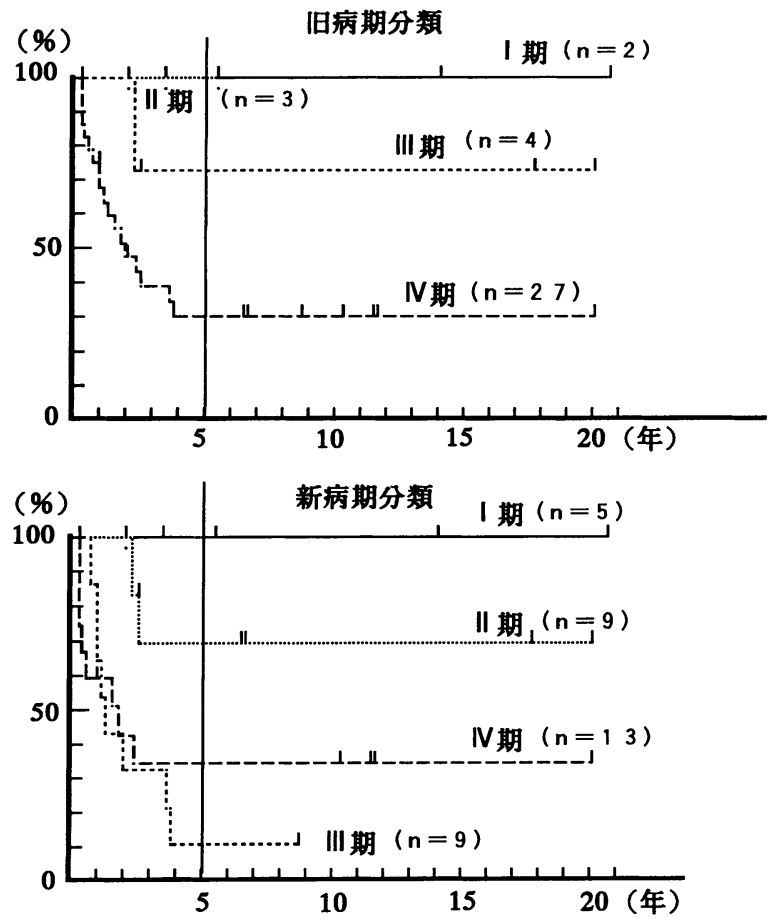

図 4 新 - 旧病期分類別生存率

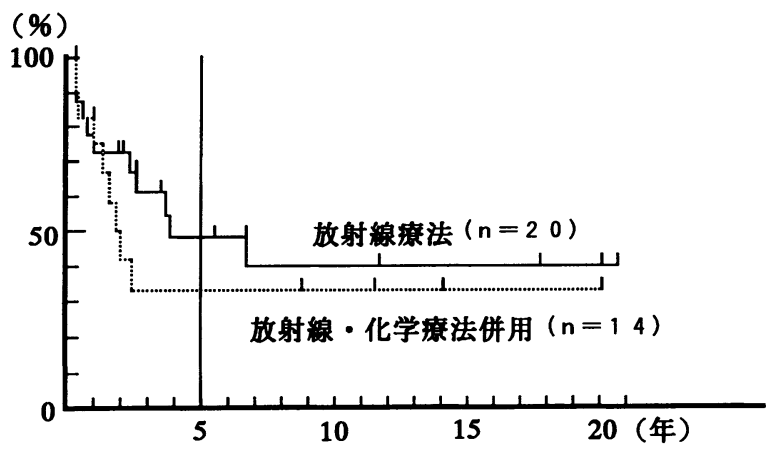

図 5 治療法別生存率

新分類では I 期 $(\mathrm{n}=5)$ が $100 \% ，$ IIB 期 $(\mathrm{n}=9)$ が 71.4 $\%$ ，III期 $(\mathrm{n}=9)$ が $11.4 \% ， \mathrm{NA}$ 期 $(\mathrm{n}=3)$ が $33.3 \% ， \mathrm{NB}$ 期 $(\mathrm{n}=7)$ が53.6\%， NC 期 $(\mathrm{n}=3)$ が $0 \%$ であった. II 期と而期の間での久有意差を認めた $(\mathrm{p}<0.05)$ (図 4$)$. 治療法別では照射単独群 $(\mathrm{n}=20)$ では 49.4\%, 照射, 化学療法併用群 $(\mathrm{n}=14)$ では $34.4 \%$ であり有意差は認め なかった(図 5 ).

6. 死亡症例

$\mathrm{M} 0$ 症例のらち死亡例は15例存在し, そのうち死因の
表 2 死亡症例内訳

\begin{tabular}{|c|c|c|c|c|}
\hline 年齢 & 病期 & 初期治療 & 再発部位 & $\begin{array}{l}\text { 再発までの } \\
\text { 期間(月) }\end{array}$ \\
\hline 74 & N B & 放射線 & 遠隔転移 & 2 \\
\hline 78 & III & 放射線 & 遠隔転移 & 6 \\
\hline 17 & III & 放射線 & 遠隔転移 & 7 \\
\hline 67 & N B & 放射線 & 遠隔転移 & 12 \\
\hline 68 & II B & 放射線 & 遠隔転移 & 20 \\
\hline 62 & III & 放射線 & 遠隔転移 & 27 \\
\hline 40 & III & 放射線＋ND & 遠隔転移 & 12 \\
\hline 66 & III & 併用 & 遠隔転移 & 9 \\
\hline 69 & III & 放射線 & 局所 & 6 \\
\hline 78 & III & 併用 & 局所 & 治療に無反応 \\
\hline 77 & N A & 併用 & 局所 & 7 \\
\hline 74 & N B & 併用 & 頸部 & 3 \\
\hline
\end{tabular}

(ND : 頸部郭清術)

明らかなものは12例であった．肺，肝，骨などの遠隔転 移で死亡していたのは 8 例 $67 \% て ゙ ，$ 治療後最短で 2 カ月， 最長で27カ月後に死亡している.これらすべての例では 局所または頸部には再発は認められなかった．治療は 6 例が放射線治療のみ, 1 例が放射線療法と頸部郭清術を 施行して招り，1 例が化学療法を併用していた。

局所再発によって死亡した例は 2 例 ( 6 力月後, 7 力 月後)で, その他 1 例は治療後も局所の腫瘍が消失しな かった。また頸部リンパ節に再発したものは 1 例 ( 3 カ 月後)であった(表 2 ).

\section{考察}

今回上咽頭癌 40 例について臨床的解析を行った. 約 20 年間といら長期間で集めた症例であったため分類法, 治 療法などの変遷もあったが, 新たに改訂された事項に関 しては診療録, 検查記録などを参考に再度分類して臨床 的検討を試みた。

上咽頭癌が男性に多く発生していることは数多くの報 告5) 14) で一致している. 年齢分布は $40 \sim 60$ 歳代にピー クをもつといら報告が多(、5) 11113)。筆者らの症例でも男 性が女性の 2 倍ほど多く, 発症年龄は 40 歳以上が 36 例と $90 \%$ 占めていた. 一方 17 歳, 20 歳の若年者の症例も存 在した. 他の報告911012)14) 16) でも10歳代の症例が散見さ れ, 若年層にも発症する本腫瘍は頭頸部癌のなかでも特 
異的であり注意が必要であると思われた.

原発部位は後上壁型が最も多く, 次いで側壁型で下壁 型は少なかった. 後上壁型と側壁型でどちらが多いかは 報告によって異なるよらである1014) 211. 下壁型はまれ

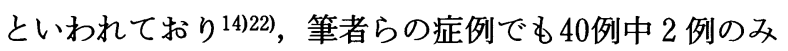
であった。

初発症状は頸部リンパ節腫脹が最も多く53\%, 次いで 耳症状が $23 \%$, 鼻症状 $18 \%$ であった. 他施設からの報 告911314)23244) でも頸部りンパ節腫脹が最も多く, 次いで 耳症状あるいは鼻症状となっている。

組織型に関しては非角化・分化型が $46 \%$ で, 未分化型, 角化型がそれぞれ27\%であった. 他の施設からの報告で は未分化型が最も多いといら報告とそうでない報告があ

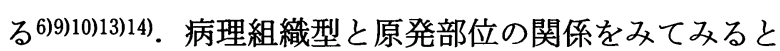
未分化型はすべて後上壁型であった. 視診で腫瘍が確認 できなかったが上咽頭から生検を施行し, 診断がついた 6 例中 4 例 $67 \%$ が未分化型であった. したがって未分化 型の特徵として腫瘤を形成せずに表面あるいは深部に浸 潤する傾向があることが推察された.

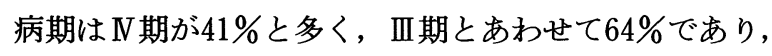
高度進展例が多く本疾患がいかに進行してから受診して いるかがわかる. UICC の TNM 分類は1997年に改訂さ れた．新分類で再分類することにより $\mathrm{T} 1$ が全症例中 35 から63\%に，N1 例が15\%から $28 \%$ に増加した。 また病 期では $\mathrm{N}$ 期から IIII期が 7 例, $\mathrm{N}$ 期から II 期が 5 例， III期 から II 期が 4 例, III期から I 期が 3 例の 19 例の病期が変 更になった．旧分類での生存率は I 期が $100 \% ，$ II 期が 100\%，正期が $75 \% ， \mathrm{~N}$ 期が $31.2 \%$ であり，I 期と II 期, II 期と III期， III期と $\mathrm{N}$ 期のいずれの間でも有意差を認め なかったが，早期 ( I 期と II 期) と進行期 (III期と $\mathrm{N}$ 期)の 間には有意差を認めた。一方, 新分類では I 期が $100 \%$,

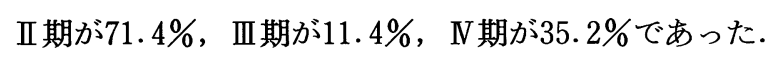

I 期と II 期， III期と $\mathrm{N}$ 期では有意差を認めなかったが II 期と III期の間で有意差を認めた。

上咽頭癌 40 症例全体の 5 年粗生存率は $45.1 \%$ であった. 治療後 3 年の間に約半数が死亡し, それ以後長期間生存 率はほとんど一定である. 5 年以上経つと予後は良好で あり, ほかの頭頸部癌と同様に治療終了後 5 年間の経過 観察が重要と思われる. 性別, 年齢, 原発部位, 病理組 織, 病期別の予後を検討してみると, 性別ではほとんど 生存率に差はないが60歳を境に 2 群に分けた場合, 60 歳 以上の症例では予後が有意に不良であった．上咽頭癌の
治療成績を性別，年齢で検討した報告は少ない，年齢に 関して検討した報告は渉猟し得た範囲ではなかったが， 性別で有意差はなかったが女性の方が予後がよかったと 述べている報告もある71025)，原発部位では下壁型 1 例 の予後が極端に悪かったが，下壁型はどの施設でも症例 数が少なく7)9101013222) 予後に関しては今後の検討事項で あると思われた. 病理組織別では未分化型の予後が比較 的良好であったが，他の型との有意差は認められなかっ た. 未分化癌は臨床的にみて進行が非常に早く, 早期に 転移する傾向が強い10) とする報告があるが，筆者らの 成績と同様に有意差はなかったが分化度が高い症例が低 分化型より予後が悪いとした報告22226) もあり今後検討 を要すると思われた。

死亡原因についてみてみると，M0症例のうち死因の

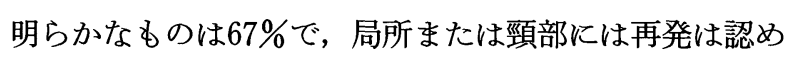
られないまま遠隔転移で死亡している. 治療成績を改善 させるためには遠隔転移への対策が必要であると考兄ら れた. 遠隔転移に対する予防, 治療は化学療法が重要で ある6(8) 1015)18). 死亡症例を検討すると, 化学療法を併 用したうち遠隔転移死した症例は 1 例のみであったこと から化学療法が遠隔転移に有効である可能性がある.し かし放射線治療のみの群と化学療法を併用した群では両 者の生存率に明らかな差はなく, 化学療法の併用は長期 予後の改善には寄与しない結果となった. このことょり 従来の方法による化学療法で上咽頭癌の予後を改善する のは困難であると思われるが, 薬剤の投与方法別に分類 して解析していないこともあり今後の検討課題である.

上咽頭癌の治療上の問題点として, 患者の免疫能の低 下が関係しているといわれている1127728). 上咽頭癌の予 後を改善するためには骨䯣移植や造血幹細胞移植を併用 した大量化学療法や免疫療法の併用などの新たな治療戦 略が必要と思われた。

\section{まとめ}

1976年から1998年までに当科で診断治療した上咽頭癌 40例について検討した.

1. 男性28例, 女性 12 例, 2.3 対 1 であった. 年齢分 布は17〜78歳, 発症のピークは60歳代にあった.

2. 原発部位は後上壁型が $68 \%$ で最も多かった. 初発 症状は頸部リンパ節腫脹が最も多く53\%であり, 耳症状 が23\%, 鼻症状が18\%であった。

3 . 病理組織型は角化型 $27 \%$, 非角化・分化型 $46 \%$, 


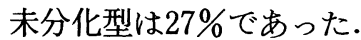

4. 病期は新分類で I 期が 5 例, IIA 期が 0 例, IIB 期が 10 例, III期が 9 例, NA期が 3 例, NB期が 9 例, $\mathrm{NC}$ 期が 4 例であった.

5. 治療は放射線単独は20例, 放射線化学療法併用は 14例であった．疾患特異的 5 年生存率は $45.1 \%$ であった。 60歳未満, 原発部位別では後上壁型が, 組織型別では未 分化型が比較的予後が良好であった。病期では I 期では 疾患特異的 5 年生存率が $100 \%$ であったが， N期では 35.2 \%であった。

\section{6. 死亡症例の $67 \%$ 遠隔転移で死亡していた.}

本論文の要旨は第24回頭頸部腫瘍学会(東京), 第 6 回北日本 頭頸部癌治療研究会(仙台)でロ演した.

\section{参考文献}

1) Decker DA, Drelichman A, Al-Sarraf M, et al : Chemotherapy for nasopharyngeal carcinoma ; a ten-year experience. Cancer $52: 602 \sim 605,1983$.

2 ) Schanmungaratnam $\mathrm{K}:$ Histological typing of tumors of the upper respiratory tract and ear. pp $32 \sim 33$, SpringerVerlag, Berlin, 1991.

3 ) UICC TNM Classification of Malignant Tumors. 4th ed (ed by Hermanek $P$ and Sobin LH). pp 19 22, SpringerVerlag, New York, 1987.

4) UICC TNM Classification of Malignant Tumors. 5th ed (ed by Sobin LH and Wittekind C). pp 25 32, John Wiley \& Sons, Inc., New York, 1997.

5 ) 村井須美子, 三吉康郎, 坂倉康夫 : 上咽頭悪性腫瘍の臨床 的観察. 耳鼻臨床 72 増 $2: 980 \sim 991,1981$.

6 ）花沢佳代子, 花沢 秀, 岡本美孝, 他: 上咽頭癌の治療成 績 -PEP-CDDP 併用の効果一. 耳鼻臨床 補57 : 159 $165,1992$.

7 ）谷口俊夫, 星野鉄雄, 藤本 弘：上咽頭癌の治療成績. 耳 鼻臨床 $78: 1943 \sim 1948,1985$.

8 ）仙波 治, 佐藤武男, 宮原 裕：上咽頭癌の治療一とく にペプレオマイシン著効例を中心として一. 耳鼻 $29: 459$ 〜65, 1983.

9 ) 藤井 守, 平川勝洋, 鈴木 衞, 他 : 上咽頭癌の臨床的観 察 一当科15年の集計一. 耳鼻臨床 補72:43 50, 1994.

10）八尾和雄, 高橋廣臣, 岡本牧人, 他：上咽頭癌51症例の治 療成績. 日耳鼻 $96: 1438 \sim 1446,1993$.

11）澤木修二：上咽頭癌. 耳喉 $50: 95 \sim 107,1978$.

12）富樫孝一，野々村直文，中野雄一：上咽頭癌の早期䛦断. 耳鼻臨床 補14：18～22, 1987.
13）渡部浩伸, 相川 通, 渡邊 睦, 他 : 上咽頭癌の臨床的観 察 一当科 10 年間の集計一.耳鼻臨床 補 $83: 150 \sim 154$, 1995.

14) Takeshita H, Furukawa M, Fujieda S, et al : Epidemiological reserch into nasopharyngeal carcinoma in Chubu region of Japan. Auris Nasus Larynx $26: 277 \sim 286,1999$.

15）佐藤公則, 松岡秀隆, 坂口伸治, 他 : 上咽頭癌に扣ける induction chemotherapy の意義. 耳鼻臨床 補80：1～6, 1995

16）兵頭政光, 湯本英二：上咽頭癌の治療成績 一追加手術の 有用性について一. 日耳鼻 $101: 1227 \sim 1233,1998$.

17）馬場駿吉, 大橋道三 : 当科過去 8 年間に扣ける上咽頭悪性 腫瘍症例の検討. 耳鼻臨床 $63: 71 \sim 84,1970$.

18）佐藤公則, 川口寿郎, 松岡秀隆, 他 : 上咽頭癌に対する Neo-adjuvant chemotherapy 一放射線併用療法一。目 鼻 $92: 2089 \sim 2093,1989$.

19）宮原 裕, 滝本加代, 佐藤武男, 他：上咽頭悪性腫瘍の臨 床的観察. 日耳鼻 $75: 355 \sim 371,1972$.

20) Johansen LV, Mestre $M$ and Overgaard J : Carcinoma of the nasopharynx; analysis treatment results in 167 consecutively admitted patients. Head Neck $14: 200 \sim 207$, 1992.

21) Scalon PW, Rhodes Jr RE, Woolner LB, et al : Cancer of the nasopharynx; 142 patients treated in the 11 year period 1950 1960. Am J Roentg 99 : 313 325, 1967.

22）吉野邦俊, 吉田疜一, 石田 稔, 他 : 上咽頭悪性腫瘍患者 107例の臨床集計. 耳鼻臨床 $73: 450 \sim 462,1980$.

23）澤木修二：上咽頭癌. 図説臨床「癌」シリーズ No. 11 頭 頸部癌 (山村雄一, 杉村 隆編). 78〜85頁, メジカルビュー 社, 東京, 1987.

24) Sham JS, Wei WI, Lau SK, et al : Serous otitis media and paranasopharyngeal extension of nasopharyngeal carcinoma. Head Neck $14: 19 \sim 23,1992$.

25）小高修司, 小野 勇, 海老原敏, 他 : 上咽頭癌の治療成績 一予後に影響を及ぼす因子の分析一。日耳鼻 $80: 1488$ 1495, 1977.

26) Bertelsen K, Andersen AP, Elbrond O, et al : Malignant tumors of the nasopharynx. Acta Radiol Ther Phys Biol $14: 177 \sim 186,1975$.

27）佃 守, 玉虫 昇, 持松いづみ, 他：上咽頭癌患者の細 胞性免疫能. 日耳鼻 $89: 7 \sim 13,1986$.

28）佃守 : 上咽頭癌 一その基礎と臨床一. Oncologica 18 : $81 \sim 93,1986$.

$\left(\begin{array}{l}\text { 原稿受付 : 平成 } 12 \text { 年 } 11 \text { 月 } 16 \text { 日 } \\ \text { 原稿採択 : 平成 } 12 \text { 年 } 12 \text { 月 } 20 \text { 日 } \\ \text { 別刷請求先 : 小林吉史 } \\ \text { 个078-8307 旭川市緑が丘東 } 2 \text { 条1-1-1 } \\ \text { 旭川医科大学耳鼻咽喉科学教室 }\end{array}\right)$

